\title{
Housing Reform, Life Course and Urban Housing Acquisition (1980-2010)
}

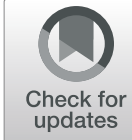

Kaize WuD

Correspondence: qqwkz@163.com Social and Public Administration School, East China University of Science and Technology, Room 232, Tuanjie Building, 130 Meilong Road, Shanghai 200237, People's Republic of China

\begin{abstract}
Based on data from the Guangzhou Household Survey in 2010 and event history model, this paper analyzes how the interactions between the housing marketization reform and individual life course affect Chinese citizens' acquisition of property rights of their first house. Research shows that the differential mode of association in housing marketization reform and diverse reform strategies have created clear period effect and cohort effect on housing acquisition. The dual housing market system, consisted of welfare housing propertization and housing commercialization, has reduced housing inequality between people within and out of the establishment, but aggravated housing inequality between the elite and non-elite, and extended the administrative elites' advantage in acquiring welfare housing. During the course of the housing reform, institutional segmentation and market differentiation have led to overlapping and mutually reinforcing types of housing inequality, exacerbating housing differentiation for the younger cohort through the intergenerational transmission.
\end{abstract}

Keywords: Welfare housing propertization, Housing commercialization, Life course, Differential mode of association

\section{Introduction}

In the late 1970s, China carried out market-oriented reforms of the welfare housing system so that the main supplier of housing supply gradually changed from the state to the market (Zhu, 2007:16-17), housing is commercialized, and housing distribution is monetized (Wang and Murie 1996; Huang and Clark 2002). Housing reform proceeded in two directions. First, welfare housing is propertized by transferring the property rights of welfare houses from work units to worker families through housing transactions in housing reform, reforming the welfare housing system (The General Office of the State Council of People's Republic of China 1988). Second, housing is commercialized by allowing for both private housing and government-subsidized private housing constructions, and encouraging foreign businesses and real estate enterprises to develop commercial housing (Zhang et al, 1998:47). Due to the long-term coexistence of the internal market and the open market in the reform process (Sato 2006), housing reform is also known as the dual-track reform (Gu \& Li, 1998, Wei, 2014).

Housing reform is also a process of adjusting urban housing wealth and benefits, which has profound impacts on social structure and individual life opportunities. Therefore, housing reform and related social inequality have been the focal points in the academic debate about the theory of market transformation (Walder 1995; Song

(c) The Author(s). 2019 Open Access This article is distributed under the terms of the Creative Commons Attribution 4.0 International License (http://creativecommons.org/licenses/by/4.0/), which permits unrestricted use, distribution, and reproduction in any medium provided you give appropriate credit to the original author(s) and the source, provide a link to the Creative Commons license, and indicate if changes were made. 
and Xie 2014). To account for the differentiation of housing property rights in the process of marketization, scholars have put forward the theory of power persistence (Bian et al, 1996; Bian and Liu, 2005), the theory of power generation, and the theory of power advantage (Liu, 2005; Logan et al. 2010; Hu, 2012; Walder and He 2014; Wei, 2015; Fu 2016), as well as the theory of market capacity and market transformation, and many other viewpoints (Li, 2004; Song and Xie 2014). Researches on housing from the market transformation perspective either focus on the propertization of welfare housing, or consist of fragmented analysis of the propertization and commercialization of housing. The acquisition of commodity housing follows the market mechanism, while the distribution of welfare housing follows the redistribution mechanism. The acquisition mode and the distribution mechanism of housing differ significantly. Therefore, research that neglects the type of housing property rights reduces the explanation power of the empirical research to the dual-track housing reform.

In the study of market transformation, scholars have adopted institutional analysis, emphasizing the influence of institutional changes at the state level on individual life opportunities (Zhou and Noen 2001). Most scholars argue that housing reform has adopted a gradual strategy (Wang and Murie 1996; Huang and Clark 2002; Bian and Liu, 2005; Li and Yi 2007; Fang, 2014), while some scholars have noted a phased and radical character of housing reform (Gu and Li, 1998; Wei, 2014). Although housing reform has generally adopted a progressive strategy, local reform practices have been more complicated. While most localities are progressive in commercializing housing, they either move from progressive to radical reform strategies or alternate between the two when it comes to housing propertization. Research on housing acquisition that builds on the progressive reform hypothesis is not sufficiently comprehensive to explain reform practices. The content and process of reform differ at different periods of the housing marketization process, and most existing researches use cross-sectional data at a specific time, which poorly reflects the dynamic change of housing marketization (Song and Xie 2014). Therefore, longitudinal data is needed to study the dynamic processes of housing acquisition in the reform process.

In the process of institutional change, spatial and temporal sources are crucial for explaining the mechanism of social inequality change and the universality of research findings. Therefore, it is necessary to distinguish spatial and temporal differences (Yang 2008). Over the past 30 years, Chinese cities have undergone major reforms and rapid social change; thus, housing research should consider the time dimension (Fu 2016). In addition, housing acquisition research that examines market transition mainly emphasizes the individual's ability to obtain a position inside the system and market capability outside the system (Li, 2004; Hu, 2012; Wang and Chen, 2013), while ignoring changes in the individual's demand for housing at different life stages (Lantz 1956; Kendig 1984) . Another notable weakness comes from ignoring cohort and period effects (Liang, 2007). Life course theory, on the other hand, attaches great importance to temporal and spatial factors. Its principle of "appropriate timing" establishes a perspective that integrates institutional change and individual life trajectories (Bao, 2005), providing a more inclusive theoretical framework for researches on the progress of the housing reform and housing acquisition (Wu \& Chen, 2014). Life course theory is also suitable for the analysis of societies that have undergone major changes and has been widely applied to the study of the impact of drastic change of national policy on individuals' life 
opportunities (Zhou and Hon, 1999; Elder 2003:1-15). Life course, as an important mirror of institutional change and individual life opportunities (Zhou and Noen 2001), is helpful for explaining the mechanism of housing acquisition in the process of housing reform (Clark et al. 1994; Huang and Clark 2002). Life course theory also has an advantage in operationalizing key links of institutional change into important events that affect housing acquisition and thereby analyzing housing acquisition from a dynamic perspective.

Taking Guangzhou as an example, this paper uses longitudinal data and an event history model to study how the interaction between the housing reform process and life process affects the acquisition of the first house with property rights. It examines cohort effects and period effects of the acquisition of the first house in the process of housing reform, and explores the macro- and microlevel impact mechanisms of the acquisition of both welfare and commodity housing property rights.

\section{Literature review and research assumptions Period effect and cohort effect of housing reform}

In the process of housing reform, Guangzhou has promoted housing commercialization by encouraging housing investment and commodity housing development, and has promoted housing propertization through housing reform. In August 1989, Guangzhou issued the "Implementation Plan of Guangzhou Housing System Reform" which started pilot housing sales; in July 1995, Guangzhou issued "Opinions on Deepening Housing System Reform in Guangzhou" to promote the sales of public housing; and in May 2000, Guangzhou issued "Notice on the Relevant Issues of Implementing Monetary Housing Allocation" to fully implement the monetization of housing allocation. The housing improvement process in Guangzhou can be divided into three periods: pilot reform (1980-1994), housing reform sales (1995-2000), and housing marketization (after 2001). The pilot reform period can be divided into the housing rental subsidy period (before 1989) and the pilot housing sales period (1990-1994). The housing marketization period can be divided into the periods of a steady increase in housing prices (2001-2005) and of a rapid increase in housing prices (2006-2010). Regarding development periods, commodity housing and welfare housing developed in parallel before 2000, after which time commodity housing dominated.

During housing property right reform, both regional and work unit levels have adopted progressive and radical reform strategies successively or alternately. At the regional level, reform before 1998 has been gradually promoted by means of pilot housing sales, rent subsidies, and promotion of rentals by sales. After 1998, radical means were adopted to stop housing distribution (Cheng, 1999:12). For example, the Guangzhou government required all enterprises and institutions to stop selling public housing and fully implemented the monetization of housing distribution from January 1, 2000. At the work unit level, because government officials often occupied larger public houses, selling houses at a low price became a priority strategy. Several sudden rounds of low-price house selling were initiated during the process of housing reform (Zhu, 2007:56-58). The reform strategy of housing property rights has given the acquisition of welfare housing a significant period effect.

The period of housing commercialization also coincided with a period of rapid urbanization in China. The national urbanization rate was $20 \%$ in 1980, exceeded $30 \%$ 
in 1996, and reached 50\% in 2010. Urbanization and housing commercialization have effectively driven the development of the real estate industry. Commodity residential investment in Guangzhou increased from 0.465 billion yuan in 1985 to 20 billion yuan in 2000, and reached 57.271 billion yuan in 2010 (Guangzhou Statistics Bureau 2011). The average sales price of commodity housing has been rising for a long time, from 882.08 yuan $/ \mathrm{m}^{2}$ in 1988 to 3978.34 yuan $/ \mathrm{m}^{2}$ in 2000 , and $10,615.09 \mathrm{yuan} / \mathrm{m}^{2}$ in 2010 (National Bureau of Statistics, China Index Academy 2011). Housing commercialization has provided new opportunities and paths for residents to acquire housing, but housing price changes have made entering the housing market more or less difficult during different periods. Based on the above analysis, hypothesis 1 is proposed.

Hypothesis 1: In the process of housing marketization, the acquisition of housing property rights has a significant period effect, i.e., the probability of housing acquisition is higher during periods of housing reform and when housing prices are steadily increasing (hypothesis of period effects).

Life course factors play a key role in regulating the impact of institutional change on individual life opportunities (Zhou and Noen 2001). The acquisition of new opportunities in the process of institutional change is impacted by the position of individual life course in many respects (Zhou, 2014:240-262). In the process of housing reform, the timing of life course has a great impact on the acquisition of housing property rights (Fu 2016). The reform strategy for housing propertization was "new systems for new comers, old methods for old cases," which means each cohort has experienced a very different institutional environment. The continuous rise in housing prices caused each cohort to face a different market environment, thus forming different cohort opportunities (Wu 2016). The cohort experiencing professional growth and achievement during the housing reform period is able to not only benefit from the property rights reform, but also take the opportunity of official promotion of housing purchase and low housing prices to buy their property. On the other hand, the cohort who were preparing for their career not only missed welfare housing, but also faced the adverse environment of rising housing prices, which makes it more difficult to buy a house. Because different cohorts in the housing reform process experience different housing opportunities, property rights acquisition has a cohort effect, and therefore, hypothesis 2 is proposed.

Hypothesis 2: In the process of housing marketization, housing property rights have a significant cohort effect. Cohorts experiencing occupational growth and achievement have an advantage during the housing reform period. Cohorts preparing for their occupation or in career decline period have no advantage (hypothesis of cohort effects).

\section{Housing property rights acquisition at all periods of housing reform Pilot reform period (1980-1994)}

Housing is the most representative welfare product in the national redistribution system of everyday living supplies. In China, the state provides housing through work units and gives out continuous subsidies. The scarcity of urban living space makes housing a symbol of welfare and status (Song and Xie 2014). Welfare housing adopts an "office-based administrative distribution mode" (Gu and Li, 1998; Li, 2002), where the closer the administrative subordinate is to the core of power, the more abundant the housing resources; the farther away from the core of power, the less abundant the 
housing resources (Wei, 2015:139). The distribution of welfare housing resources presents a similar "differential mode of association" as proposed by Fei Xiaotong (2012: 13-17). Whether workers can obtain housing, as well as the environment of surrounding areas and residential facilities, is all related to their work unit's capacity to build housing and power to control and distribute housing (Bian et.al, 1996). The propertization of welfare housing also implicates a "differentiated treatment" that starts from the work units at the system's outside or margins, and closes in onto the core work units (Wei, 2017). This policy is extended to public and administrative institutions after having been experimented in state-owned and collective enterprises, which also reflects the characteristics of "the differential mode of association." According to the policy for housing sale during the housing reform, cadre families and worker families can only enjoy a one-time preferential treatment when purchasing houses, and thus, delaying the purchase means the opportunity to switch to or buy newer and larger public houses (Mao, 2014). With the influence of the stigmatization of private property rights, which was still present at the beginning of the reform, the advantaged social classes were unlikely to willingly purchase a welfare house (Wang and Chen, 2013). To mitigate difficulties faced by urban low-income families, Guangzhou built poverty relief housing that was sold to extremely challenged households-those with less than $5 \mathrm{~m}^{2}$ per capital living area, successfully solved the housing problem for 11,642 special poverty-stricken households from 1986-1991 (Liu et al., 2012:142-143). Therefore, in the pilot phase of the social housing reform, welfare housing was often provided to workers who had lower occupational status or were retired.

Due to the exclusiveness of the welfare housing system, welfare housing was difficult to access for employees of private and foreign-funded enterprises and other institutions. Scholars of the market transition theory believe that the market can, to a certain extent, offset inequalities caused by redistribution, thereby benefiting the direct producers, the technical elite, and the lower class (Polany, 2007:4; Szelenyi 1978). In the pilot reform phase, the government supports the development of the real estate industry and encourages developers to build commodity housing (Zhang 1997). The self-employed and employees of private enterprises and other institutions have lower occupational status but higher income and thus entered the real estate market earlier to purchase housing (Lee 2000; Zhu, 2007:123). Therefore, the commercialization of housing in the early phase included some equalizing effects, and people of ordinary classes can benefit from the expansion of the housing market (Szelenyi 2010:152-193). To this end, the following assumptions are made:

Hypothesis 3.1: In the pilot reform phase, individuals who are acquiring property rights for welfare housing mostly are the non-elite stratum in the system.

Hypothesis 3.2: In the pilot reform phase, employees of non-institutional units will mostly purchase property rights of commodity housing.

\section{Housing reform sales period (1995-2000)}

The welfare housing system is a closed system, which makes obvious the housing division between institutional and non-institutional units. Work units at higher administration levels obtain more housing benefits (Li, 2002). China started the housing reform during a time of housing shortages, because the allocation of welfare housing resources 
presents a "differential mode of association," and work units with advantages in the power system also have advantages in terms of housing property rights (Liu and Mao, 2012; $\mathrm{Hu}, 2012)$; the work unit system and the power to redistribute became important mechanisms for housing inequality in the housing reform period (Liu, 2005). Within the work unit, assigned housing serves as a reward for political loyalty and a compensation for low wages (Wang and Murie 1996). Work units assign housing to members who are "more useful" to society according to their title, seniority, political "progressiveness," and family conditions (Huang and Clark 2002; Bian et al., 1996). The welfare housing distribution system, in which professional elite within the system receives newer and higher quality housing, led to the accumulation of social privilege (Szelenyi 2010: 63-86). Driven by concerns with potential resistance from those with vested interests in the status quo, work units recognize and protect the existing housing allocation structure when selling houses (Zhu, 2007: 116-121). As a result, establishment elites have become winners in welfare housing propertization (Bian and Liu, 2005; Logan et al. 2010; Walder and He 2014). Their housing advantages are mainly reflected in the quality, rather than the property right, of their housing (Wei, 2017).

During the sales period of the housing reform, work units within the establishment bought a large amount of commodity housing from the market and assigned them to its employees according to preferential policies of the housing reform (Cheng, 1999: 386; Wei, 2017). Statistics show that from 1995-1998, 39.3\% of commodity houses in Guangzhou were sold to work units (Guangzhou Statistics Bureau 2000). The government also provides a variety of preferential policies and housing provident funds for workers of these work units who sought to buy houses in the market (Wei, 2014). With the development of the housing market and rising house prices, housing property rights are more readily accessible to families with higher occupational status inside and outside the system (Huang 2004). Due to factors such as the little qualitative difference and the huge price difference between commodity housing and welfare housing, the disqualification for welfare housing after a commodity housing purchase, and the influence of the real estate bubble of the 1990s, establishment elites preferred not to buy commodity housing prior to the end of housing reform (Mao, 2014). To this end, the following assumptions are made:

Hypothesis 4.1: During the sales period of the housing reform, work units inside the system benefit more from acquiring welfare housing property rights than work units outside the system, and work units with administrative ranks benefit more than those without.

Hypothesis 4.2: During the sales period of the housing reform, work units inside the system benefit more from buying commodity housing property rights than work units outside the system, and administrative elites are unlikely to willingly purchase commodity housing.

\section{Housing marketization period (2001-2010)}

In the aftermath of the sales period of the housing reform, China has gradually established a mixed real estate market consisted of a highly monopolistic land transfer market and a highly commercialized housing market. On the one hand, the real estate industry has been established as a pillar industry of the national economy for its promotion of economic growth (The State Council 2003), and thus, housing has become an important commodity 
and investment; on the other hand, local governments have monopolized the land supply through land reserve and the bidding system, making profound intervention into the real estate market. The land bidding system and the reform of the tax sharing system pushed local governments and real estate enterprises into a long-term alliance based on lands, which has maintained the high housing prices (Fu 2013). China's real estate market has both market and redistribution features, as the market adjustment mechanism has not replaced the deep-rooted influence of the unit system (Ho and Kwong 2002).

During the housing marketization period, with the work unit system being stringent and institutional changes gradual, work units inside the system continued to be protected by government power (Wu, 2010), and work units still played an important role in housing acquisition (Huang and Clark 2002). In the process of institutional change, work units changed from "administrative units" to "interest-oriented units," with their central task transitioning to satisfying their members' needs and seeking organizational selfdevelopment (Sun et al., 1994). Against the backdrop of the rapid rise in housing prices, a reversed marketization emerged in the real estate market, in which the establishment elite acquired housing in non-market or semi-market ways (Fang, 2014). State-owned work units and housing management agencies were still allowed to sell their worker's public houses that were left. In "Measures for the management of economically affordable housing" issued by the Ministry of Construction in 2007, housing constructed with work units' collective funds was still defined as economically affordable housing. The abstract and vague nature of the housing policies provided work units with land and housing construction resources with the opportunity to seek favorable housing resources (Hu, 2012). Some localities adopted "entrusted construction" or "targeted housing development" to build housing for civil servants (Chen, 2009); some state-owned enterprises used the land they owned to build luxury collectively funded housing and then sold the houses to their management and employees at prices far below market value. Because the reform remained partialized, administrative elites saw opportunities to use their power in the redistribution economy (Nee 2002:183216), and they still have the upper hand in welfare housing acquisition.

During the process of real estate development, multiple administrative approvals are required. As a result, work units inside the system have more bargaining power in the market. Some families may use their political resources and power to obtain price discounts, preferential loans, insider information, and so on, and acquire high-quality housing (Song and Xie 2014). But on the whole, the vast majority of unit workers bought commodity houses at market prices, and as a result, system differences in commodity housing acquisition gradually shrank. Individuals mainly depend on their own economic ability for purchasing commodity housing, and economic ability is closely related to education level and occupational status; thus, housing marketization benefits the elite class rather than the ordinary citizens (Davis 2003:183-198). Although administrative elites inside the system can benefit from the commercialization of their bureaucratic privileges (Szelenyi and Kostello, 2002:574-589), they are more inclined to obtain welfare housing because of the cost concerns. Professional elites participate in market competition with professional and technical abilities, demonstrating "advantages" in the commodity housing market. To this end, the following assumptions are proposed:

Hypothesis 5.1: During the period of housing marketization, work units inside the system have a greater advantage in acquiring welfare housing property rights than those outside the system have, and administrative elites receiving more benefit than the non-elites. 
Hypothesis 5.2: During the period of housing marketization, there was no obvious system difference in the acquisition of property rights for commodity housing, but professional elites have more advantages than the non-elites.

\section{Data and methods}

\section{Source of data}

This paper uses data from the "Guangzhou Urban Housing Survey" conducted in 2010 by Sun Yat-sen University's Center for Studies of Hong Kong, Macao and Pearl River Delta (2010 Guangzhou Thousand Household Survey). Using multistage cluster sampling, the survey drew samples from six central-city districts-Yuexiu, Haizhu, Liwan, Tianhe, Baiyun, and Huangpu. All respondents had their household registered in Guangzhou. Household heads-the major providers of their families' economic income-were identified with a screening questionnaire. Finally, face-to-face structured interviews were conducted with the identified respondents (Liu and Mao, 2012). 1120 survey questionnaires were distributed, among which 1115 were returned and 1,039 were valid responses. In addition to asking respondents about their current occupation and housing status, the retrospective tracing approach was used to obtain each respondent's detailed housing history and relative work history. These include, among others, the occupation and work unit of themselves, their spouses, and their parents when the current house was required, as well as the type and level of the couple's work unit and their individual administrative level and occupational title when obtaining other houses. This paper uses the information on the household heads and their spouses to represent the family situation.

We have deleted observations with self-built housing and private housing in self-built form, first house purchase made before 1980, or the buyer of the house less than 15 years old, resulting in 114 surveys being removed, leaving 925 valid observations. According to the family housing history and time points of life events, person-year data groups were created for respondents over 15 years old between 1980 and 2010. A total of 31 data files were created, containing longitudinal data with 24,510 person-year values.

\section{Research variables}

The dependent variable, housing property rights, denotes whether or not the respondent or their spouse has full of partial property rights of their first house. The variable takes the value of 1 if they have obtained the property rights and 0 if they rent their house.

The type of housing is either rental housing, commodity housing, or welfare housing. Rental housing includes the privately owned rentals, municipal public houses, work unit public houses, and low-rent houses. Commodity housing includes first-hand commodity housing and second-hand commodity housing (including purchased private housing). Welfare housing includes housing reform houses, poverty alleviation houses, settlement houses, work unit collectively funded houses, and economically affordable housing.

All independent variables, with the exception of gender, are time-varying variables during the observation period, which include the following:

Period. According to the three periods of the housing reform process (1980-1994, 1995-2000, 2001-2010) and the key junctures such as the years 1990, 1998, and 2005, seven periods are identified. 
Career development stage. Based on existing research (Super 1980) and the career developmental pattern of urban residents, five stages are defined: "career preparation" (before the age of 19), "entrance" (ages 20-24), "development" (ages 25-39), "achievement" (ages 40-54), and "decline" (after the age of 55).

Birth cohort. Respondents are categorized into nine cohorts, each with 5 years apart, according to their year of birth.

Occupation. Categories include "managerial and professional employees," "technical and service employees," "individual entrepreneur," "physical laborer," and "without job" (i.e., when the respondent is unemployed or has opted not to work in the observed year). The "managerial and professional employees" category is seen as the elite class.

Type of the work unit. Based on the relative position of the respondent's work unit vis-à-vis the establishment, each unit is categorized as either state-owned institutions (including administrative agencies and the public sector), state-owned and collective enterprises, or non-establishment enterprises (including respondents who do not belong to a work unit).

Level of the work unit. If either the respondent's or their spouse's work unit in the observed year is above the district level, the unit is categorized as "having administrative level," otherwise "no administrative level."

Educational attainment. Categories include "middle school and below," "high school and technical secondary school," and "technical college and above."

Administrative rank and occupational title. If either the respondent or their spouse has an occupational title or an administrative rank, the respondent is seen as "having administrative rank," otherwise "no administrative rank." In this paper, those who have occupational titles are labeled "professional elites" and those who have administrative ranks are labeled "administrative elites."

\section{Modeling methods}

This paper uses discrete-time event history models to investigate the acquisition of housing property rights, commodity housing, and welfare housing, at different stages of China's housing reform. Event history models integrate relevant information of the life course through time-varying variables. They can also adequately deal with the issue of censorship ( $\mathrm{Du}, 2008$ : 37-42). By resetting the original data, event history models can be estimated with the dichotomous variable logit model and the multivariate mlogit model (Wu 2008). The logit model is expressed by the following formula:

$$
\ln \frac{p(t)}{1-p(t)}=b_{1} x_{1}+b_{2} x_{2}+\cdots+b_{k} x_{k}
$$

where $p(t)$ is the rate of risk-or the probability of an event occurring to the individual observed at time $t$-and the expression $\ln \frac{p(t)}{1-p(t)}$ is the logit transformation of $p(t)$.

The mlogit model estimates a set of logit regression equations at once (Tang, 2012:317318). Taking rental housing as the reference group, the ratio of other categories to the reference group is calculated by the formula below:

$$
\ln \frac{p(\mathrm{Y}=j / X)}{p(Y=0 / X)}=a_{\mathrm{i}}+\sum_{k=1}^{k} b_{k \mathrm{i}} X_{k}
$$


In Formulas 1 and $2, X_{1}$ through $X_{k}$ denote the explanatory variables, and $b_{1}$ through $b_{k}$ denote their corresponding regression coefficients.

The event history models are set up in the following manner. The starting year is set at 1980, and the ending year is set at 2010. Respondents begin to be at risk at the age of 15 . They exit the risk group after obtaining the housing property rights. There are 16,611 risky person-years. Missing values of relevant variables are dealt with using column deletion, resulting in 903 individual observations and 15,522 person-year values included in the models. The hazard rate for obtaining the housing property rights is 0.69 , and the average survival time is 17.19 years. Among all individual observations included in the model, 622 have obtained housing. Consisting 351 commodity housing and 271 welfare housing were obtained. Table 1 presents the descriptive statistics of the relevant variables.

Table 1 Descriptive statistics of relevant variables

\begin{tabular}{|c|c|c|c|c|c|}
\hline & Person-years & Percentage & & Person-years & $\overline{\text { Percentage }}$ \\
\hline \multicolumn{3}{|c|}{ Housing property rights } & \multicolumn{3}{|l|}{ Educational attainment } \\
\hline Rental housing & 14,900 & 95.99 & Middle school and below & 3488 & 22.47 \\
\hline $\begin{array}{l}\text { Housing property } \\
\text { rights }\end{array}$ & 622 & 4.01 & $\begin{array}{l}\text { High school and technical } \\
\text { secondary school }\end{array}$ & 10,036 & 64.66 \\
\hline Birth cohort & & & Technical college and above & 1998 & 12.87 \\
\hline Before 1939 & 293 & 1.89 & Political status & & \\
\hline 1940-1949 & 625 & 4.03 & Non-party members & 15,207 & 97.97 \\
\hline 1950-1954 & 875 & 5.64 & CPC party members & 315 & 2.030 \\
\hline 1955-1959 & 1902 & 12.25 & Type of the work unit & & \\
\hline 1960-1964 & 4116 & 26.52 & Non-establishment enterprises & 8727 & 56.22 \\
\hline 1965-1969 & 3193 & 20.57 & State-owned institutions & 2410 & 15.53 \\
\hline 1970-1974 & 2520 & 16.24 & $\begin{array}{l}\text { State-owned and collective } \\
\text { enterprises }\end{array}$ & 4385 & 28.25 \\
\hline 1975-1979 & 1267 & 8.16 & Level of the work unit & & \\
\hline 1980-1990 & 731 & 4.71 & No administrative level & 8032 & 51.75 \\
\hline Period & & & Having administrative level & 7490 & 48.25 \\
\hline 1980-1994 & 8956 & 57.70 & Occupation & & \\
\hline $1995-2000$ & 3428 & 22.08 & Physical laborer & 6138 & 39.54 \\
\hline $2001-2010$ & 3138 & 20.22 & $\begin{array}{l}\text { Managerial and professional } \\
\text { employees }\end{array}$ & 1828 & 11.78 \\
\hline Age & & & Technical and service employees & 1996 & 12.86 \\
\hline $15-19$ & 2837 & 18.28 & Individual entrepreneur & 2710 & 17.46 \\
\hline $20-24$ & 3231 & 20.82 & Without job & 2850 & 18.36 \\
\hline $25-39$ & 7214 & 46.48 & Administrative rank & & \\
\hline $40-54$ & 1977 & 12.74 & No administrative rank & 14,814 & 95.44 \\
\hline After 55 & 263 & 1.690 & Having administrative rank & 708 & 4.56 \\
\hline Gender & & & Occupational title & & \\
\hline Female & 8130 & 52.38 & No occupational title & 13,501 & 86.98 \\
\hline Male & 7392 & 47.62 & Having occupational title & 2021 & 13.02 \\
\hline
\end{tabular}




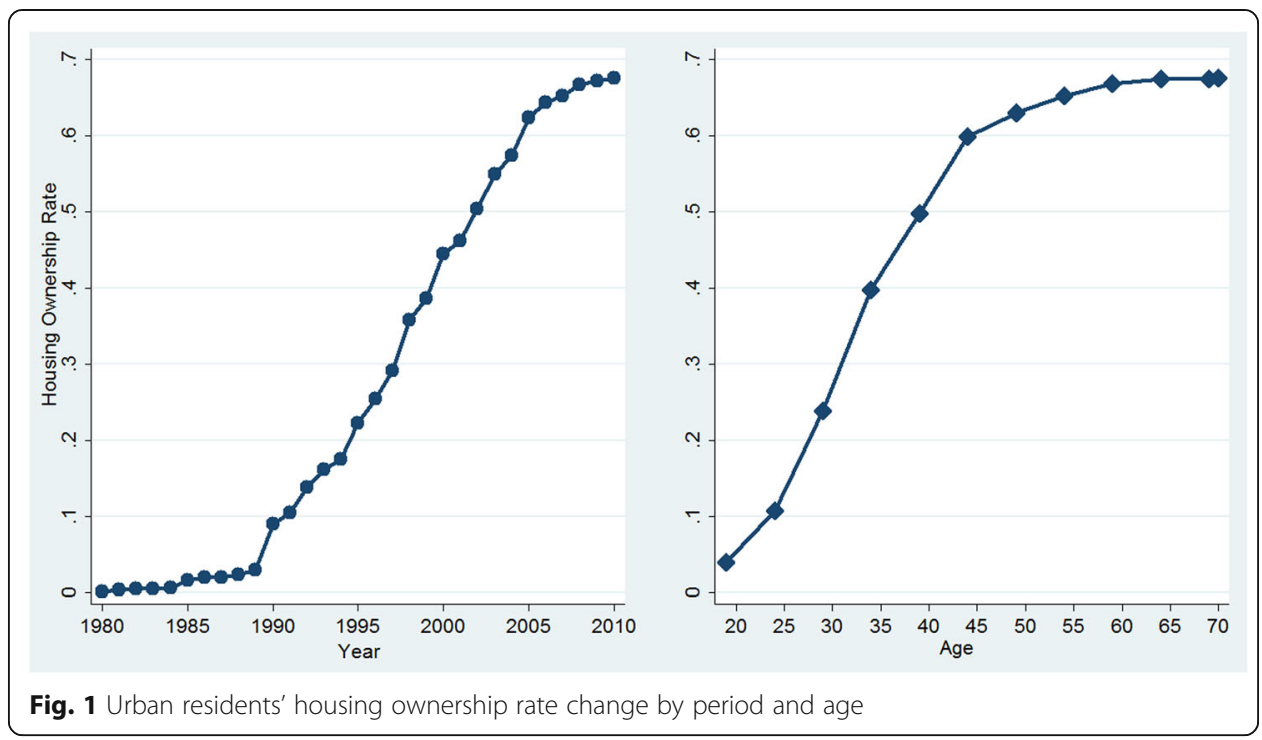

\section{Acquisition of urban housing property rights (1980-2010)}

\section{Description of housing property rights acquisition}

Under the combined influence of the housing reform and the development of the housing market, the acquisition of housing property demonstrates noticeable period effects. At the early stages of the housing reform, housing ownership grew very slowly. After the experimental pilot sales, housing ownership rate rose from 3\% in 1989 to $9 \%$ in 1990. During the housing reform sales period and the steady housing price increase period (1995-2005), private ownership rate grew significantly to 62.3\%. During the period in which housing prices rapidly rose, the increase in private ownership slowed down. Housing acquisition also exhibits an age effect, so that private ownership significantly increases among ages 25 to 44 and stabilizes after the age 55 (Fig. 1).

Housing ownership rate shows significant cohort differences. More than $90 \%$ of the 1940s own their houses, while $75 \%$ of the 1930 s, the 1950 s, and the 1960 s and $55 \%$ of the 1970s and the 1980s do. Adjacent cohorts differ significantly in housing ownership. Fourteen percent less people own their houses in the 1930s than in the 1940s; the 1950-1954 cohort lags 9\% behind the 1955-1959 cohort. For each cohort, the period in which their housing ownership significantly increased happened at different times. For the 1960s and older cohorts, significant ownership increases occurred during the pilot reform and housing reform sales periods, while the 1970s and the 1980s have significant ownership growth during the housing reform sales period and the steady housing price increase period. The age effect also plays out distinctively for each cohort. Younger cohorts purchase their houses at increasingly younger ages-almost no one in the 1940s obtained housing ownership by the age of 39 , but $58 \%$ of the 1980 s obtained housing ownership by the age of 29 (Fig. 2).

\section{Risk and survival estimates of housing property rights acquisition}

In the observation period, the hazard rates of housing property rights acquisition demonstrate an inverted $U$ trend, steadily increasing during the pilot housing sales period and housing reform sales period (1990-2000) and gradually decreasing during the housing 
marketization period. The same trends emerge in the hazard rates of housing property rights acquisition among different cohorts also. The 1980s hazard rate steadily increases during the steady housing price increase period and decreases in the period of a rapid increase in housing prices. The 1940s has the highest hazard rate peak; the 1970-1974 cohort has a low peak followed by a rapid decline; the 1980s has both a high starting value and a high peak (Figs. 3 and 4).

From the KM cumulative survival estimate graph, we see continuous increases in housing ownership during the housing reform sales period and steady housing price increase period. Each generation varies significantly in housing ownership. The 1940s, who were at their career achievement stage during the housing reform sales period, has a housing ownership rate over $90 \%$. The 1930 s, who moved into their career decline stage, and the 1950s and the 1960s, who were at their career development stage, have ownership rates between $75 \%$ and $80 \%$. The ownership rates for the 1970 s, who were at the career entrance stage, and the $80 \mathrm{~s}$, who were at the career preparation stage, are around $60 \%$.

\section{Results}

Period and cohort effects on the acquisition of housing property rights

As shown by model 2 in Table 2, prior to the year 2000, under the strong influence of the progress of the propertization reform, the housing reform sales period saw the higher probability of obtaining housing property rights. Events during the housing reform also affected housing acquisition in certain periods. For example, the pilot sales policies enacted during 1989-1990 and the stoppage of housing distribution policies during 1998-2000 both resulted in higher acquisition in the respective periods than their adjacent periods. Thus, significant period effect emerged from the successive use of gradual and radical reform strategies. In the housing marketization period, housing is influenced by changes in housing prices. Ownership rates are higher when housing prices steadily increased. Hypothesis 1 is supported.

The acquisition of housing property rights has a considerable cohort effect. As shown in model 3, the odds ratio of obtaining housing property rights is $1.69\left(\mathrm{e}^{0.527}\right)$ for the 1930s without statistical significance, $2.43\left(\mathrm{e}^{0.889}\right)$ for the 1940s with great statistical significance, larger than 1.5 for both the 1950s and the 1960s with passable significance, and 1.16 for the 1970-1974 cohort without statistical significance. Looking at the cohort housing opportunities, most of the 1930s were in their career decline stage during the housing reform sales period and therefore have little advantage in obtaining housing. The 1940s and the 1950-1954 cohort were in the career achievement stage, and the 1955-1959 cohort and the 1960s were in their career development stage. They are able to enjoy assigned welfare housing and also take advantages of flexible loans and low housing prices to purchase houses. Most of the 1970s were in the career preparation or career entrance stages, and they not only missed assigned welfare housing, but also face the unfavorable environment with rising housing prices. Unexpectedly, the odds ratio for housing acquisition is $1.96\left(\mathrm{e}^{0.677}\right)$ for the 1980s, with great statistical significance, so we failed to support hypothesis 2 . Model 3 also shows a lower odds ratio and significance for the 1950-1954 cohort, compared with their adjacent cohorts, although they were in the career achievement stage during the housing reform sales period. Life course theory argues that differences between adjacent cohorts are the 
Table 2 Discrete-time event history analysis of housing property rights acquisition (1980-2010)

\begin{tabular}{|c|c|c|c|}
\hline & Model 1 & Model 2 & Model 3 \\
\hline Gender (female $=0$ ) & $-.09260(.085)$ & $-.06000(.086)$ & $-.08970(.087)$ \\
\hline \multicolumn{4}{|l|}{ Education level (middle school and below $=0$ ) } \\
\hline High school and technical secondary school & $.0865(.112)$ & $-.00025(.114)$ & $.0245(.120)$ \\
\hline Technical college and above & $.727^{* * *}(.147)$ & $.277^{*}(.149)$ & $.440^{* * *}(.159)$ \\
\hline Party members (no. $=0$ ) & $.352(.230)$ & $.792^{* * *}(.239)$ & $.704^{* * *}(.248)$ \\
\hline \multicolumn{4}{|c|}{ Type of the work unit (enterprises outside the system $=0$ ) } \\
\hline State-owned institutions & $.247^{*}(.146)$ & $.498^{* * *}(.146)$ & $.404^{* * *}(.148)$ \\
\hline State-owned and collective enterprises & $.334^{* * *}(.126)$ & $.595^{* * *}(.127)$ & $.491^{* * *}(.130)$ \\
\hline Level of the work unit(No=0) & $.170^{*}(.101)$ & $.227^{* *}(.102)$ & $.202^{* *}(.103)$ \\
\hline \multicolumn{4}{|l|}{ Occupation (physical laborer =0) } \\
\hline Managerial and professional employees & $.0761(.156)$ & $.242(.159)$ & $.175(.163)$ \\
\hline Technology and service worker & $.0759(.135)$ & $-.0206(.137)$ & $.0164(.139)$ \\
\hline Individual entrepreneur & $.457^{* * *}(.141)$ & $.578^{* * *}(.143)$ & $.549 * * *(.145)$ \\
\hline Without job & $-.577^{* * *}(.180)$ & $-.12900(.183)$ & $-.22000(.201)$ \\
\hline Occupational titles (no. $=0$ ) & $.224 *(.132)$ & $.269^{* *}(.134)$ & $.259 *(.136)$ \\
\hline Administrative ranks (no. $=0$ ) & $-.17000(.189)$ & $-.29000(.196)$ & $-.30500(.197)$ \\
\hline \multicolumn{4}{|l|}{ Period $(2006-2010=0)$} \\
\hline 1980-1988 & & $-2.478^{* * *}(.287)$ & $-2.553^{* * *}(.291)$ \\
\hline 1989-1990 & & $-.07970(.207)$ & $-.11400(.212)$ \\
\hline 1991-1994 & & $-.323^{*}(.189)$ & $-.331^{*}(.193)$ \\
\hline 1995-1997 & & $.415^{* *}(.179)$ & $.428^{* *}(.183)$ \\
\hline 1998-2000 & & $.960^{* * *}(.172)$ & $.979^{* * *}(.174)$ \\
\hline $2001-2005$ & & $.931^{* * *}(.169)$ & $.942^{* * *}(.170)$ \\
\hline \multicolumn{4}{|l|}{ Birth cohorts $(1975-1979=0)$} \\
\hline Before 1939 & & & $.527(.370)$ \\
\hline 1940-1949 & & & $.889^{* * *}(.261)$ \\
\hline 1950-1954 & & & $.434^{*}(.253)$ \\
\hline 1955-1959 & & & $.571^{* * *}(.207)$ \\
\hline 1960-1964 & & & $.566^{* * *}(.186)$ \\
\hline 1965-1969 & & & $.473^{* *}(.185)$ \\
\hline 1970-1974 & & & $.152(.188)$ \\
\hline 1980-1990 & & & $.677^{* * *}(.218)$ \\
\hline Constant terms & $-3.624^{* * *}(.148)$ & $-3.801^{* * *}(.203)$ & $-4.185^{* * *}(.246)$ \\
\hline Person-years & 15522 & 15522 & 15522 \\
\hline Pseudo $R^{2}$ & .0254 & .1164 & .1211 \\
\hline Log likelihood & -2543.98 & -2306.94 & -2294.38 \\
\hline
\end{tabular}

${ }^{*} p<0.10$

${ }^{* * *} p<0.05$

**** $p<0.01$ (two-tailed test)

Standard errors in parentheses

largest in rapid transformations; hence, the cohort difference is induced by institutional transformation (Elder 2002:443). Moreover, the addition of period and cohort variables effectively improved the fit of the model, speaking to the need to consider time dimension when studying housing acquisition Table 2. 


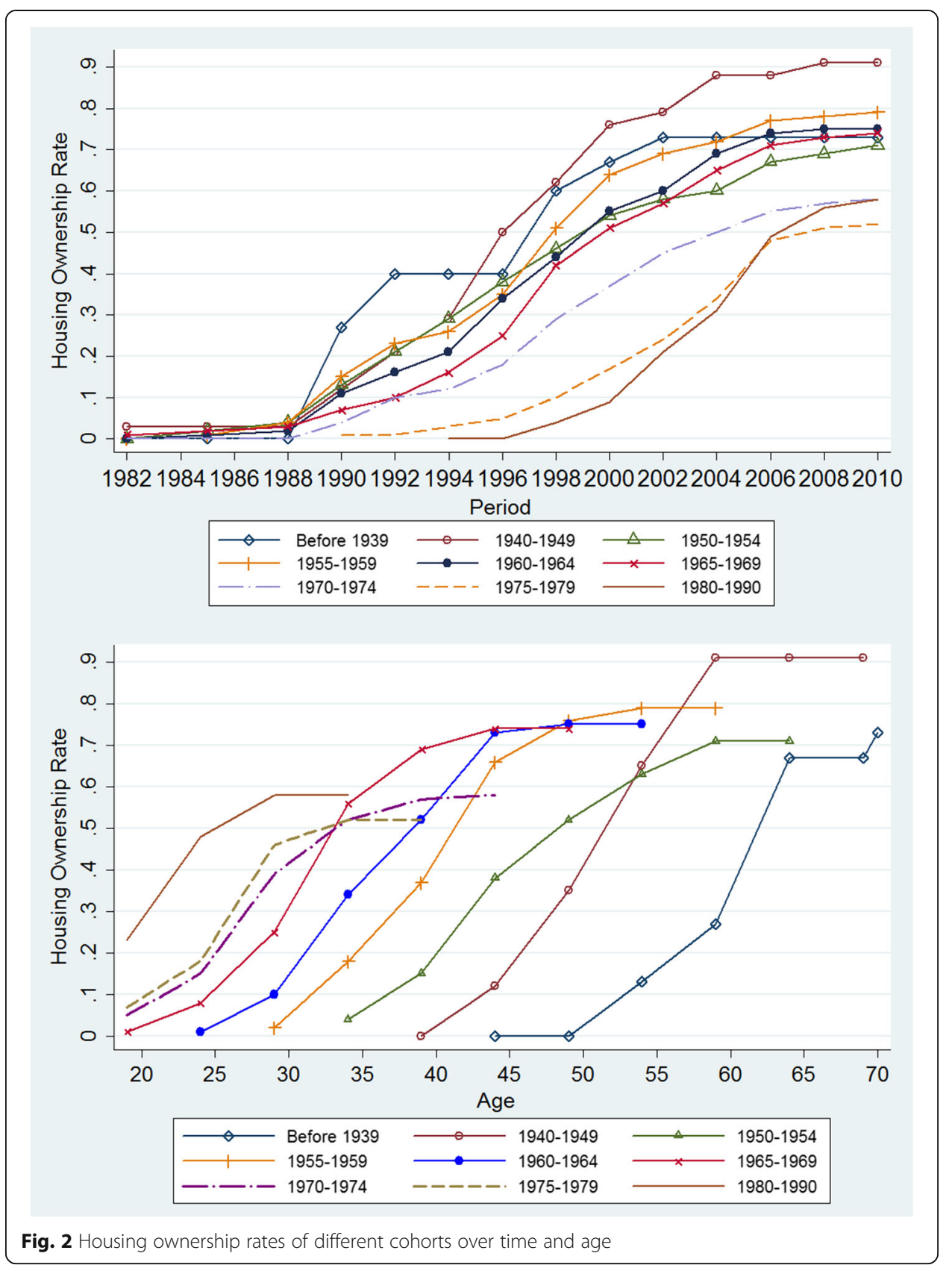

The 1980s has a relatively high housing ownership rate despite limited wealth accumulation, and high housing prices reflect the change of housing acquisition mechanism for younger cohorts. In all individual observations, the average age of housing property rights acquisition is 17.65 for the 1980s, and near $80 \%$ of their housing acquisition was funded by their parents. After removing observations with parental financial help from the sample, the 1980s ownership rate dropped from 0.81 to only 0.46. During the housing marketization period, housing acquisition becomes more and more dependent on family economic capability, rather than the work unit, and family wealth difference has become a crucial factor causing housing differentiation in the younger cohorts Table 3. 
Table 3 Housing ownership of each cohort and parental financial support for the first house

\begin{tabular}{|c|c|c|c|c|c|}
\hline \multirow[t]{2}{*}{ Cohorts } & \multicolumn{2}{|l|}{ All samples } & \multicolumn{2}{|c|}{$\begin{array}{l}\text { After removing samples with } \\
\text { parental financial support }\end{array}$} & \multirow{2}{*}{$\begin{array}{l}\text { Proportion } \\
\text { of parental } \\
\text { financial } \\
\text { support }\end{array}$} \\
\hline & $\begin{array}{l}\text { Average age of } \\
\text { housing property } \\
\text { rights acquisition }\end{array}$ & $\begin{array}{l}\text { Housing } \\
\text { ownership } \\
\text { rate }\end{array}$ & $\begin{array}{l}\text { Average age of } \\
\text { housing property } \\
\text { rights acquisition }\end{array}$ & $\begin{array}{l}\text { Housing } \\
\text { ownership } \\
\text { rate }\end{array}$ & \\
\hline Before 1939 & 60.75 & .80 & 58.90 & .75 & 16.67 \\
\hline 1940-1949 & 51.84 & .94 & 51.69 & .94 & 9.09 \\
\hline 1950-1954 & 45.48 & .86 & 46.14 & .79 & 31.82 \\
\hline 1955-1959 & 39.54 & .90 & 39.84 & .85 & 29.89 \\
\hline 1960-1964 & 36.58 & .86 & 36.50 & .79 & 30.56 \\
\hline 1965-1969 & 32.32 & .87 & 32.81 & .81 & 32.90 \\
\hline 1970-1974 & 27.89 & .74 & 29.41 & .60 & 44.17 \\
\hline 1975-1979 & 25.16 & .73 & 26.84 & .55 & 47.89 \\
\hline 1980-1990 & 17.65 & .81 & 21.89 & .46 & 79.55 \\
\hline
\end{tabular}

\section{Acquisition of housing property rights during the pilot reform period}

During the pilot reform period, party membership, age, and occupational title have significant positive correlation with housing property acquisition, while work units within the system, administrative level of work unit, and individual's administrative rank have negative correlation. It is hard to reconcile the fact that individuals at their career decline stage and workers with occupational titles are advantaged in housing property acquisition, but establishment administrative elites are disadvantaged without regarding the differences between the distribution mechanisms of commodity housing and welfare housing. As shown in model 2, for the acquisition of welfare housing property rights, the coefficients of state-owned institutions and state-owned and collective enterprises are -0.348 and -0.170 , respectively. This means work units within the system



Fig. 3 Risk estimates for acquisition of the first housing property rights for each cohort 
had no advantages during the pilot reform period. The managerial and professional employees category and those with administrative rank have coefficients of, respectively, -1.146 and -0.969 with statistical significance, meaning that most of those who acquired property rights of welfare housing during the pilot reform period do not belong to the elite class. Administrative elites would not willingly purchase welfare housing. The age effect is shown in the odds ratio of the career achievement and career decline stages, respectively, $3.29\left(\mathrm{e}^{1.190}\right)$ and $9.68\left(\mathrm{e}^{2.270}\right)$ with great statistical significance, indicating most recipients of welfare housing are retired workers. Hypothesis 3.1 is supported. In addition, the higher a worker's education attainment, the more likely they are to receive welfare housing. Party membership and occupational title also have significant positive correlations. These illustrate that pilot sales are a continuation of the distributive logic of the redistribution system.

Regarding the acquisition of commodity housing during the pilot reform period, the within-system work units negatively correlate with housing acquisition, the unit administrative level has a negative coefficient with statistical significance, and the managerial and professional employees category has an insignificant coefficient. Workers of within-system units are unlikely to voluntarily purchase commodity housing. The ratios of individual administrative rank and party membership are both 0 , indicating the elite class's unwillingness to purchase commodity housing. In terms of the age effect, the ratio of the career development stage is $3.47\left(\mathrm{e}^{1.245}\right)$ and significant, whereas the career decline stage has a ratio of 0 . As such, most of those who obtained commodity housing during the pilot reform period were non-establishment individuals who were in their career development stage. Hypothesis 3.2 is supported.

\section{Housing property rights acquisition during the housing reform sales period}

Age and work unit type have significant effects on housing acquisition during the housing reform sales period. Workers of within-system units, workers at their career achievement or career decline stage, managerial and professional employees, and individual entrepreneurs all have significant advantages. For welfare housing, there are significant positive effects from work units that are within the system and have administrative level. The closer the work unit is to the center of the establishment, the larger the coefficient is: state-owned institutions and state-owned and collective enterprises have coefficients of 1.221 and 1.060, respectively, and both are with great statistical significance. The work unit's level has a significant correlation coefficient of 0.681 . As housing reform sales came to a close, establishment work units such as state-owned institutions and enterprises expedited housing sales, crystallizing the housing resource advantage enjoyed by central establishment work units into housing property advantages. Regarding career factors, being in the managerial and professional employees category yields a positive but insignificant correlation coefficient. Occupational title has a negative correlation, whereas individual administrative rank has a positive coefficient, indicating a relative advantage for administrative elites over professional elites and supporting hypothesis 4.1 .

For commodity housing acquisition, state-owned institutions have a positive correlation, and state-owned and collective enterprises have a positive and significant correlation with acquisition. This reflects that establishment work units also enjoy advantages in 
commodity housing acquisition. Looking at occupational types, both the managerial and professional employee category and the individual entrepreneur category have positive and significant correlation coefficients, indicating the elite class's advantage in obtaining commodity housing. Occupational title has a positive coefficient, while individual's administrative rank has a negative coefficient, indicating professional elites' advantages and administrative elites' unwillingness to purchase commodity housing in the housing reform sales period. Hypothesis 4.2 is supported. In addition, the cohort at their career achievement stage has advantages in the acquisition of commodity housing, showing the realization of educational advantages.

\section{Acquisition of housing property rights in the housing marketization period}

During the housing marketization period, the age at acquiring housing property rights shows an apparent decreasing trend, with the correlation coefficients of the career development stage and the career decline stage being -0.653 and -0.612 , respectively. Workers of within-system units do not have a noticeable advantage in housing acquisition anymore. Technical and service employees and individual entrepreneurs obtain advantages. For welfare housing, state-owned institutions and state-owned and collective enterprises each has a ratio of $2.15\left(\mathrm{e}^{0.765}\right)$ and 2.31 $\left(\mathrm{e}^{0.836}\right)$, respectively, and both are significant. This attests to the differential mode of association in the housing marketization reform, in which work units within the establishment still enjoy power protection in the housing marketization period and get to keep their advantages in obtaining property rights of welfare housing. The managerial and professional employees category has a positive but insignificant correlation coefficient. Individual administrative rank has a ratio of $3.21\left(\mathrm{e}^{1.168}\right)$ that is very significant. Occupational title has a negative but insignificant coefficient. These coefficients of occupation type, administrative rank, and occupational title show that administrative elites have significant advantages over any other nonelites when it comes to the acquisition of welfare housing, supporting hypothesis 5.1 .

Two apparent trends emerge from commodity housing acquisition. First, residents with higher education background have significant advantages, with those who have degrees from technical colleges or above having a statistically significant ratio of 2.19 (e0.785). Second, the age of housing property rights acquisition shows an apparent decreasing trend, with those at the career development and achievement stages seeing a negative correlation coefficient and the "disappearance" of their advantages in housing acquisition. Looking at work-unit types, state-owned institutions have a negative coefficient, while state-owned and collective enterprises have a positive but insignificant coefficient, indicating little systematic differentiation in the acquisition of commodity houses. Occupational title has a significant positive correlation, while individual administrative rank has a positive but insignificant correlation, pointing to the advantage of professional elites over others. Hypothesis 5.2 is therefore supported. Results in model 9 shows that the housing commercialization reform had broken the acquisition advantage enjoyed by withinsystem work units. Acquisition of commodity houses mostly depends on occupational status and economic capability Table 4. 







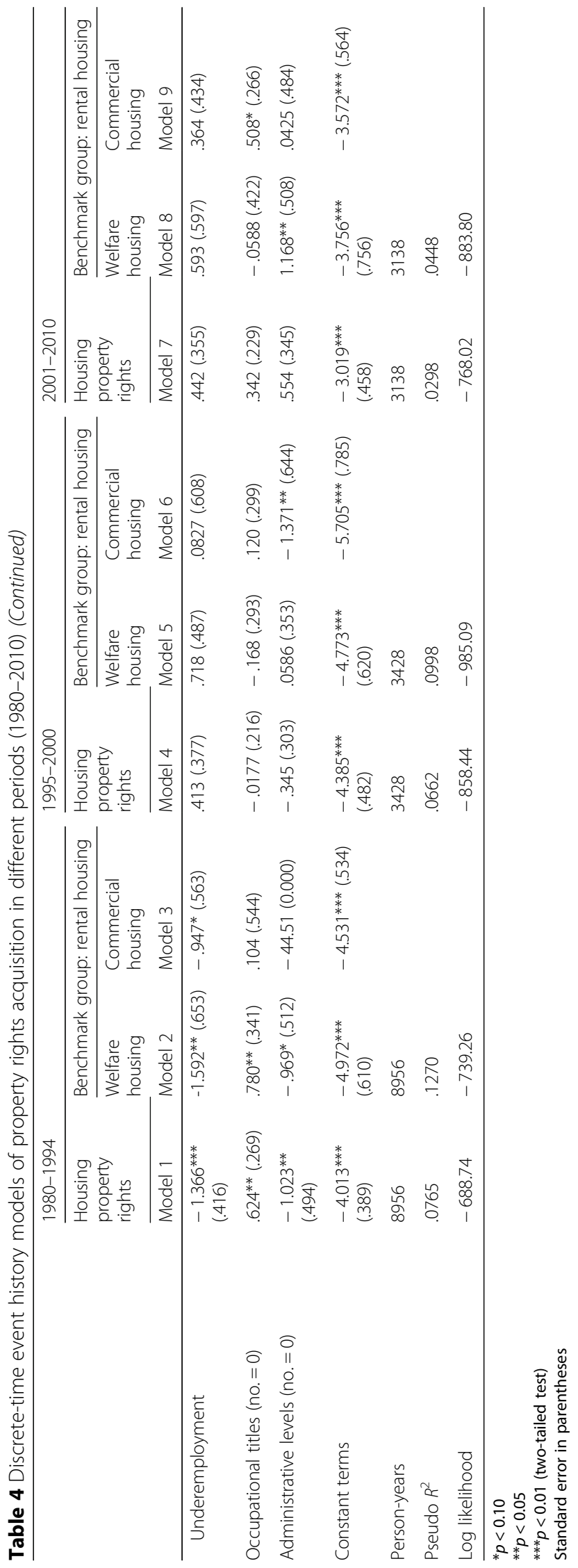




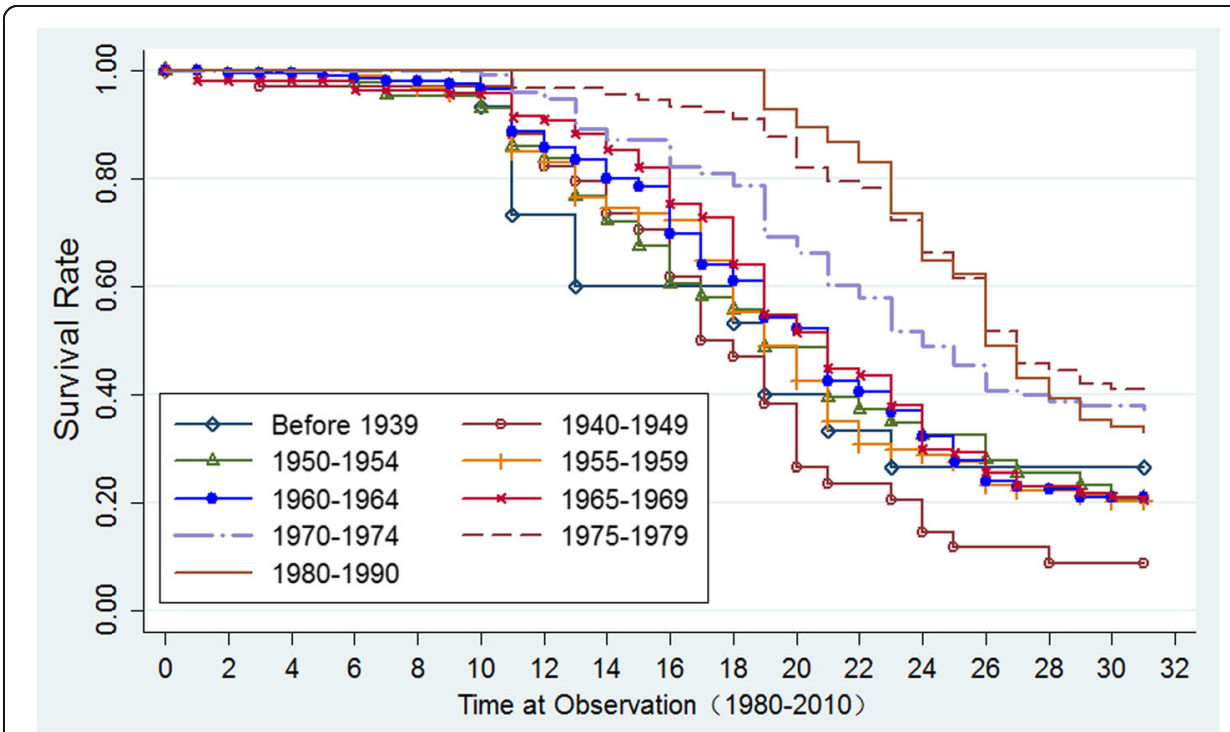

Fig. 4 Kaplan-Meier cumulative survival estimates for acquisition of the first housing property rights for each cohort

\section{Conclusion and discussion}

In the past more than 30 years, China has been promoting the housing marketization reform "with two driving wheels." On one hand, market mechanisms were introduced to push for the commercialization of housing; on the other, housing reform sales were implemented to push for the propertization of welfare housing. Different periods of the housing marketization reform entail different contents and processes, and studies that use cross-sectional data obtained at certain time point could not effectively reflect the evolutional path and effect mechanism of housing inequality, leading to inadequate conclusions. As such, research on the market transformation of housing must systematically investigate the dual-track reform, in order to understand the dynamic changes of the reform process. This paper uses housing history data to examine the interactional effect from the combination of the reform process of welfare housing propertization and housing commercialization and the individual life course on housing acquisition. The study has uncovered the duality in the housing market transformation resulted from the dual-track reform model; while the acquisition of commodity housing gradually comes to depend on the market mechanism, the acquisition of welfare housing perpetuates the redistribution mechanism.

Chinese urban housing has experience a marketization reform which consisted of three stages-pilot reform, housing reform sales, and marketization. In the reform process, housing commercialization has adopted a gradual reform strategy, while housing propertization either successively move from gradual to radical reform strategies or alternate between the two, producing significant period and cohort effects for the acquisition of housing property rights. The hazard rates of housing acquisition for all cohorts demonstrate an inverted $\mathrm{U}$ trend, with the probability of acquisition the highest in the reform sales period and the steady housing price increase period, and low when housing prices rapidly inflates. In the process of housing marketization, life courses of different cohorts interact with the reform, producing generational differentiation in housing. Those who were at their career development or achievement stages during the housing reform sales period-the 1940s, 1950s, and 
1960s-have advantages, while the 1970s has a lower ownership rate. Family-funded housing purchase introduced new changes into the cohort effect. The 1980s has a relatively high ownership rate despite continuously rising housing prices.

This paper reveals the differential treatment of welfare resource allocation and housing marketization. The allocation of welfare housing follows the principle of "differential mode of association." The higher the work unit's administrative level and the closer it is to the center of the establishment, the more housing benefits it has. The marketization reform also follows the sequence of differential mode of association, starting from the outside or margins of the establishment and gradually moving towards to work units at the center. Work units closer to the establishment center enter the market later and get more power protection. As such, at present, work units still influence the acquisition of housing property rights. Workers of work units in the system have advantages not only in acquiring welfare and commodity housing during the housing reform sales period, but also in welfare housing acquisition during the marketization period. Because of the co-existence of the welfare housing allocation model and the housing marketization model, advantaged social classes tend to adopt differential strategies at different stages in order to realize their own housing interests.

China's housing reform has established a highly marketized commodity housing market, broken the single supply mode of the welfare housing system, and paved a new path for housing acquisition. Housing marketization enables workers of work units inside or outside of the system establishment to participate in the market competition on a fairer basis. Non-establishment individuals could benefit from the development of the housing market, thus reducing housing inequality. Szelenyi and colleagues have asserted that the equalizing effect of the market can only be short term during the transition process and further market development would exacerbate inequality. In the housing marketization period, beneficiaries of housing propertization and commercialization reforms could compete in the market at an advantaged position, possibly getting more houses. However, groups with lower socioeconomic status would find it difficult to solve their housing issue through the market. Systematic division and market differentiation mutually reinforce each other and produce a superposing effect that exacerbates housing differentiation. Data from the Thousand Household Survey of Guangzhou shows a decline in the probability of acquiring the first house since the year 2006, but an increasing probability to purchase the second house. Most of those who have multiple properties obtained their first house either during the housing reform sales period or with parental financial help (Wu 2016). Early beneficiaries in the commercialization and propertization reforms are engaging in intergenerational transfer of property wealth through the housing market. Therefore, younger cohorts still have high rates of housing acquisition in spite of the high housing prices. As such, the differential effect produced by the combination of systematic division and market differentiation is deepening the housing differentiation among younger cohorts through intergenerational transfer. This might be an important social source of young adults' "housing anxiety" nowadays.

In today's Chinese cities, a stratification based on housing has emerged. This "three-leveland-five-category" structure consists of "no property," "one property," and "multiple properties" classes (Liu and Mao, 2012). Housing property rights have a significant impact on social classes. Housing differentiation can exacerbate wealth inequality between social classes and deepen internal conflicts within the social structure (Xu, 2002). Without policy 
intervention, the Matthew Effect of the housing market could worsen wealth inequality and influence social stability. To lessen such inequality induced by housing market differentiation, housing security policies that target the property poverty group are essential. The differential mode of association of housing resource allocation and the path dependency of interested work units prone to cause digression in the dual-track housing policies against the backdrop of rapid housing price increase. That is, within-system work units are likely to prioritize solving the housing issue of their employees with non-market means. This paper has found that in terms of acquisition of welfare housing during the marketization period, employees of work units within the establishment and administrative elites enjoy significant advantages. This is illustrated when, under imperfect access and exit mechanism of housing security, it is still possible for people not in poverty to obtain housing security resources. As such, the design of the housing institution must consider how to crack the differential mode of association in housing allocation, as well as negative effects from interested work units, in order to ensure the fairness of the institution.

This paper has made a major contribution by investigating the progression of housing marketization from the perspective of institutional changes and with the retrospective housing history data. This approach overcomes the shortcoming of cross-sectional data, namely, that it cannot reflect the dynamic changes of the dual-track housing reform, and thereby extended researches on the evolutionary path of the housing marketization. Another contribution of this paper lies in the integration of life courses and the housing reform to study the impact of macrolevel institutional changes on individual life chances. We are able to reveal how the period and cohort effects of housing acquisition have been impacted by both the gradual and the radical strategies of propertization, as well as by the fluctuations of the housing market.

Certainly, this paper has many shortcomings. For example, the housing market in different regions of China is highly differentiated. Retrospective survey data also has some limitations. Longitudinal data of wider ranges and longer tracks is needed for more comprehensive and deeper research. Moreover, after the year 2010, the real estate market has experienced great changes.The continual rise of housing prices has made the wealth effect of housing obvious, and houses have to a great extent turned from the consumer goods into an investment and financial good. The financialization of housing intensifies by the day, worsening societal wealth inequality. The government has frequently adjusted both the market and housing policies in order to solve citizens' housing problem, giving new features to the dual-track housing system. Due to data limitations, this paper could not dive into the housing stratification against the backdrop of housing financialization, which is extremely crucial for future housing institutions. This might be the next direction for housing research.

Acknowledgements

The author would like to thank Professor Zuyun Liu for his meticulous guidance and Professor Ning Wang, Yucheng Liang, Cuntong Wang and Ms. Ying Li for their advice.

Authors' contributions

The sole author takes the sole responsibility for the content of his article. The author read and approved the final manuscript. 
Public Housing Supply and Service Mechanism" project of the Foundation of Shanghai Soft Science Research Program (No.: 18692104700), and the Fundamental Research Funds for the Central Universities.

\section{Availability of data and materials}

The data in this paper is from the "Guangzhou Urban Housing Survey," which was conducted by the Center for Studies of Hong Kong, Macao and Pearl River Delta of Sun Yat-Sen University in 2010.

This survey's raw data should not be shared due to the institution's data copyright policy (the Center for Studies of Hong Kong, Macao and Pearl River Delta).

\section{Competing interests}

The author declares that there are no competing interests.

Received: 20 March 2019 Accepted: 13 June 2019

Published online: 25 July 2019

\section{References}

Bao, L.P. 2005. Reflects On the View of Time in Life-Course Theory. Sociological Studies 4: 120-133.

Bian, Y.J., R.R. John, H.L. Lu, Y.K. Pan, and Y. Guan. 1996. The Work Unit System and Housing Commercialization. Sociological Studies 1: 83-95.

Bian, Y.J., and Y.L. Liu. 2005. Social Stratification, Home Ownership, and Quality of Living: Evidence from China's Fifth Census. Sociological Studies 4: 82-98.

Chen, H. 2009. China's civil servants housing should not enjoy 'supra-citizen' treatment. China Construction 7: 6-7.

Cheng, S.W. 1999. Reform of Urban Housing System in China: Target Model and Difficulties in Implementation. Beijing: Democracy and Construction Publishing House.

Clark, W.A.V., M.C. Deurloo, and F.M. Dieleman. 1994. Tenure changes in the context of micro level family and macro level economic shifts. Urban Studies 31 (1): 137-154.

Davis, D.S. 2003. From welfare benefit to capitalized asset: the re-commercialization of residential space in urban China. In Housing and social change: east-west perspectives, ed. R. Forrest and J. Lee. New York: Routledge.

Du, B.F. 2008. Event history analysis and its application. Beijing: Economic Science Press.

Elder, G.H. 2002. Children of the great depression. In Tian He, Ma Chunhua Trans. Nanjing: Yilin Press.

Elder, G.H. 2003. The emergence and development of life course theory. In Handbook of the life course, ed. M.K. Johnson and R. Crosnoe. NewYork: Springer.

Fang, C.C. 2014. Institutional Segmentation and Housing Inequality in Urban China. Chinese Journal of Sociology (Chinese version) 34 (3): 92-116.

Fei, X.T. 2012. From the soil: the foundations of Chinese society. Beijing: Peking University Press.

$\mathrm{Fu}, \mathrm{Q}$. 2013. Local state marketism: an institutional analysis of China's urban housing and land market. Chinese Sociological Review 46 (1): 3-24.

Fu, Q. 2016. The persistence of power despite the changing meaning of home ownership: an age-period-cohor analysis of urban housing tenure in China, 1989-2011. Urban Studies 53 (6): 1225-1243.

Gu, S.Z., and Z.Y. Li. 1998. The Reform of Double-track Housing System and the Start-up of Housing Market. Sociological Studies 6: 105-112.

Guangzhou Statistics Bureau, 2000, 50 years in Guangzhou http://210.72.4.58/portal/querylnfo/statisticsYearbook/index.

Guangzhou Statistics Bureau, 2011, Guangzhou statistical yearbook 2011 http://210.72.4.58/portal/querylnfo/ statisticsYearbook/index.

Ho, M.H., and T.M. Kwong. 2002. Housing reform and home ownership behavior in china: a case study in Guangzhou. Housing Studies 17 (2): 229-244.

Hu, R. 2012. Housing Inequality during the Market Transition: Evidence from the Data of CGSS2006. Chinese Journal of Sociology (Chinese version) 32 (1): 126-151.

Huang, Y.Q. 2004. The road to home ownership: a longitudinal analysis of tenure transition in urban China (1949-94). International Journal of Urban and Regional Research 28 (4): 774-795.

Huang, Y.Q., and W.A. Clark. 2002. Housing tenure choice in transitional urban china: a multilevel analysis. Urban Studies 39 (1): 7-32.

Kendig, H.L. 1984. Housing careers, life cycle and residential mobility: implications for housing market. Urban Studies 21 (3): 271-283.

Lantz, H.R. 1956. Why families move: a study in the social psychology of urban residential mobility. American Sociological Review 21 (3): 395

Lee, J. 2000. From welfare housing to home ownership: the dilemma of China's housing reform. Housing Studies 15 (1): 61-76.

Li, B. 2002. The segregation of China's housing reform system. Sociological Studies 2: 80-87.

Li, B. 2004. Empirical Study on the Relationship between the Position Capacity and the Acquisition of Housing Benefits of Urban Unit Workers. Journal of Central South University (Social Science) 10 (2): 166-171.

Li, S.M., and Z. Yi. 2007. The road to home ownership under market transition Beijing, 1980-2001. Urban Affairs Review 42 (3): 342-368.

Liang, Y.C. 2007. Decomposing the Effects of Modernization Transition and Marketing Transition: Marketing Transition Research Model with Age, Cohort, and Period Effects. Sociological Studies 4: 93-117.

Liu, X. 2005. Housing Inequality in Chinese Cities. In Fudan Sociological Review, 1st ed. Shanghai: Shanghai SDX Joint Publishing Company.

Liu, Z.Y., and X.P. Mao. 2012. Housing stratification in urban China: a study based on a Guangzhou household questionnaire survey. Social Science in China 1: 94-109.

Liu, Z.Y., et al. 2012. Research on housing security in Guangzhou and Hong Kong. Beijing: China Social Science Press. 
Logan, J.R., Y.P. Fang, and Z.X. Zhang. 2009. Access to housing in urban China. International Journal of Urban and Regional Research 33 (4): 914-935.

Logan, J.R., Y.P. Fang, and Z.X. Zhang. 2010. The winners in China's urban housing reform. Housing Studies 25 (1): 101-117.

Mao, X.P. 2014. House purchasing: housing stratification and self-selected mobility in institutional transition. Chinese Journal of Sociology(Chinese version) 34 (2): 118-139.

National Bureau of Statistics, China Index Academy. 2011. China real estate statistics yearbook. Beijing: China Statistics Press.

Nee, Victor. 2002. A theory of market transition: from redistribution to market. In Market Transition and Social Stratification American Sociologist's Analysis of China, ed. Y.J. Bian et al. Beijing: SDX Joint Publishing Company.

Polanyi, K. 2007. The Great Transformation: The Political and Economic Origins of Our Time, Feng, G., and X.Y. Liu. Trans. Hangzhou: Zhejiang People's Publishing House.

Sato, H. 2006. Housing inequality and housing poverty in urban China in the late 1990s. China Economic Review 17 (1): 37-50.

Song, X., and Y. Xie. 2014. Market transition theory revisited: changing regimes of housing inequality in China, 1988-2002. Sociological Science 1: 277-291.

Sun, L.P., H.S. Wang, and S.B. Wang. 1994. Changes in China's social structure since the reform. Social Science in China 2: 47-62.

Super, D.E. 1980. A life-span, life-space approach to career development. Journal of Vocational Behavior 16 (3): 282-298.

Szelenyi, I. 1978. Social inequalities in state socialist redistributive economies. International Journal of Comparative Sociology 19 (1-2): 63-87.

Szelenyi, I., and E. Kostello. 2002. The Market Transition Debate: toward a Synthesis? In Market Transition and Social Stratification - American Sociologist's Analysis of China, ed. Y.J. Bian et al. Beijing: SDX Joint Publishing Company.

Szelenyi, Ivan. 2010. Imagination of neo-classical sociology. In Lv, P., J.Z. Liu, Y.Y. Wang, X. Wen, trans. Beijing: Social Sciences Academic Press.

Tang, Q.M. 2012. Quantitative data analysis: testing ideas through social research. Ren, Q. trans. Beijing: Social Sciences Academic Press.

The General Office of the State Council of People's Republic of China, 1988, "The notice on forwarding 'opinions on encouraging workers to purchase public old housing' issued by the leading group on housing system reform of the state council" (The General Office of the State Council [1988] No. 13). ((1988)13).

The State Council, 2003, "The State council notice on promoting the sustained and healthy development of the real estate market" (the State Council [2003] No. 18)

Walder, A.G. 1995. Local governments as industrial firms: an organizational analysis of China's transitional economy. American Journal of Sociology 101 (2): 263-301.

Walder, A.G., and X. He. 2014. Public housing into private assets: wealth creation in urban China. Social Science Research 46 (3): 85-99.

Wang, N., and S. Chen. 2013. The Change of China's Urban Housing Property Rights Differentiation Mechanism: An Empirical Study based on Guangzhou (1980-2009). Journal of Lanzhou University (Social Science) 41 (4): 1-12.

Wang, Y.P., and A. Murie. 1996. The process of commercialization of urban housing in China. Urban Studies 33 (6): 971-989.

Wei, W.Q. 2014. Institutional Change and Evolutionary Characteristics of Housing Inequality of Urban Residents in China. Jianghan Tribune 5: 136-140.

Wei, W.Q. 2015. Research on Urban Residents' Housing Problems in the Background of Social Transition: from the Perspective of Housing Stratum Theory. Wuhan: Huazhong University of Science and Technology Press.

Wei, W.Q. 2017. Occupational status and housing acquisition: 'the differential mode of association' in urban housing reforming. Lanzhou Academic Journal 3: 175-190.

Wu, K.Z. 2016. Research on urban resident's second set of housing acquisition from life course perspective. Chinese Journal of Sociology(Chinese version) 36 (1): 213-240.

Wu, K.Z., and L. Chen. 2014. From Life Cycle to Life Course: Review and Prospect on Chinese and Western Housing Acquisition. Urban Studies(Chinese version) 21 (12): 7-13.

Wu, X.G. 2008. Communist cadres and market opportunities: entry into self-employment in China (1978-1996). In Social Stratification and Social Mobility: New Progress in Chinese Studies by Foreign Scholars, ed. X.G. Wu, Y.J. Bian, and L.L. Li. Beijing: China Renmin University Press.

Wu, Z.Z. 2010. The interaction of institutional change and its stratification effect: an analysis based on the reform of working unit system and housing system. Social Science 1: 71-77.

Xu, B.X. 2002. The impact of intergenerational housing transfer on the cognition of social classes: an observation of Taiwan society in 1990s. Journal of Housing Studies 11 (1): 55-78.

Yang, Y. 2008. Social in equalities in happiness in the United States, 1972 to 2004: an age-period-cohort analysis. American Sociological Review 73 (2): 204-226.

Zhang, H.M. 1998. Housing Economics. Shanghai: Shanghai University of Finance and Economics Press.

Zhang, X.Q. 1997. Chinese housing policy, 1949-1978: the development of a welfare system. Planning Perspectives 12 (4): 433-455.

Zhou, X.G. 2014. Economic Transition and Life Opportunities: a Perspective of Life Course, In Zhou, X.G. The State and the Life Chances in Urban China: Redistribution and Stratification 1949-1994. Hao, D.H.i et al. trans, Beijing: China Renmin University Press.

Zhou, X.G., and L. Hou. 1999. Children of the cultural revolution: the state and the life course in the People's Republic of China. American Sociological Review 64 (1): 12-36.

Zhou, X.G., and P. Noen. 2001. Explaining life chances in China's economic transformation: a life course approach. Social Science Research 30 (4): 552-577.

Zhu, Y.P. 2007. Housing Reform in China: Policy Innovation and Housing Equity. Guangzhou: Sun Yat-sen University Press.

\section{Publisher's Note}

Springer Nature remains neutral with regard to jurisdictional claims in published maps and institutional affiliations. 